\title{
Ethnobotany of an indigenous tree Piliostigma thonningii (Schumach.) Milne- Redh. (Fabaceae) in the arid and semi-arid areas of South Omo Zone, southern Ethiopia
}

\author{
Mesfin Belete Hailemariam ${ }^{1,2^{*}}$, Zerihun Woldu², Zemede Asfaw² and Ermias Lulekal ${ }^{2}$
}

\begin{abstract}
Background: Trees are important components of terrestrial ecosystems; they provide ecological, economic, and cultural services to humans. There is an urgent need for undertaking ethnobotanical investigations and documentation on the indigenous botanical knowledge of the local communities of a given area. This study was conducted to assess and document the categoric ethnobotany of Piliostigma thonningii and the associated indigenous knowledge of the local people related to use, management practices, and the threatening factors in the South Omo Zone of southwestern Ethiopia.

Materials and methods: Six Kebeles were purposively selected from two districts of the zone and a total of 84 respondents were sampled, with consideration of gender, age, and wealth status. Data were collected using structured and semistructured interviews, field observations, and group discussions. Relevant descriptive statistical methods were used to analyze the data. Ethnobotanical knowledge held by informants were computed using Pearson's chi-square test and direct matrix ranking and pair-wise ranking was used to prioritize the uses according to community preferences and the level of the destructiveness of the reported threats.

Results: The results showed that $P$. thonningii provides different functions to people's livelihoods as shade, food, fodder, soil fertility, fuelwood, medicine, rope, multipurpose materials (e.g., Borketa for sitting and head support), huts, beehives, farm implements, chairs, fences, and timber. The indigenous knowledge of local people on the uses of $P$. thonningii has shown significant $(P<0.05)$ relationship to age groups (being higher for elderly people). The consumption practice of respondents has significant $(P<0.05)$ association to the Kebeles, age, and income, with higher value for Hamer, lower aged groups, and low-income families. It provides nutritious animal feed to improve browse intake, survival, and productivity of domestic animals and also improve productivity of farm through amelioration of soil fertility. The status of $P$. thonningii has been decreasing due to agricultural expansion, collection of the species for firewood, dry fencing, and due to browsing. Respondents' attitude and interest to maintain and conserve the species has shown a significant $(P<0.05)$ association to gender, wealth, and level of education. Higher interest was observed in men than women, mid-high wealth class households than low income, and people with education than uneducated.
\end{abstract}

\footnotetext{
*Correspondence: msbd2006@gmail.com

'Department of Biology, Wolkite University, Wolkite, Ethiopia

${ }^{2}$ Department of Plant Biology and Biodiversity Management, Addis Ababa

University, Addis Ababa, Ethiopia
}

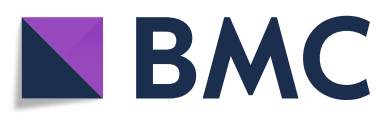

(c) The Author(s). 2021 Open Access This article is licensed under a Creative Commons Attribution 4.0 International License, which permits use, sharing, adaptation, distribution and reproduction in any medium or format, as long as you give appropriate credit to the original author(s) and the source, provide a link to the Creative Commons licence, and indicate if changes were made. The images or other third party material in this article are included in the article's Creative Commons licence, unless indicated otherwise in a credit line to the material. If material is not included in the article's Creative Commons licence and your intended use is not permitted by statutory regulation or exceeds the permitted use, you will need to obtain permission directly from the copyright holder. To view a copy of this licence, visit http://creativecommons.org/licenses/by/4.0/ The Creative Commons Public Domain Dedication waiver (http://creativecommons.org/publicdomain/zero/1.0/) applies to the data made available in this article, unless otherwise stated in a credit line to the data. 
Conclusions: This study attempted to provide information on the multiple uses of $P$. thonningii. Given the key roles of $P$. thonningii for the people and the environment to improve household food security, agricultural productivity, and income sources and the threats to it, the need to protect it in natural forests and woodlands and optimize its uses in agroforestry systems is high. Serious consideration of this species will ultimately allow households to reap the benefits expected to accrue from it in the arid and semi-arid areas of Ethiopia where plants of this nature are usually rare.

Keywords: Benna-Tsemay, Consumption, Ethnic group, Hamer, Indigenous knowledge, Multiple uses, Piliostigma thonningii, South Omo Zone

\section{Introduction}

\section{Background of the study}

Piliostigma thonningii (Schumach.) Milne-Redh. is common in open woodland and wooded grasslands of subhumid Africa at medium to low altitudes. It is widely distributed and found throughout tropical Africa except in Somalia [1]. In Ethiopia, it occurs in deciduous woodlands and wooded grasslands in most parts of the country [2].

Piliostigma thonningii is one of the most important indigenous multipurpose trees used for various purposes [3]. It is used as source of food for humans in Benna-Tsemay and Hamer Districts of South Omo Zone, locally known as Olofoo (Benna and Hamer) [4]. Its occurrence and uses have been studied in Quara area of north Gonder [5], and Benishangul Gumuz region [6]. P. thonningii is known as Monkey bread or Camel's foot in English and Kameel Spoor in Africans [7]. Reports by Tadesse et al. [8], Amente [6], Tebkew et al. [5], and Ayenew [9] showed that P. thonningii is also consumed by animals as a fodder. However, in other African countries, $P$. thonningii is used for various purposes other than food. Sources show that the different parts of the tree (leaves, pods, and seeds) which are nutritious are browsed by animals including elephants, livestock, and antelopes $[1,10-13]$. The leaves of $P$. thonningii are eaten and chewed by the Masai people to relieve thirst [12].

The wood is suitable for poles, firewood, charcoal, carpentry, construction, to make household utensils, and farm implements $[1,2,10]$. The bark is used to make strings, ropes, and clothes $[1,2,11]$. Different phytochemicals (such as flavonoids, tannins, alkaloids, saponins, terpenoids, anthraquinones, steroids, and volatile oils) are extracted from the parts of $P$. thonningii and used to treat various diseases, such as fever, toothache, wound healing, dysentery, respiratory ailments (bronchitis, cough, and chest complaints), snake bites, hookworm, skin infections, stomach ache, and chronic ulcers [1, 12-18]. In Tanzania, the tender leaves are chewed and the juice is swallowed to treat stomach-ache, coughs, and snakebite [19]. The roots are used to treat prolonged menstruation, hemorrhage, and miscarriage in women and also for the treatment of coughs, colds, body pain, and STDs [19].

Ethnobotanical knowledge on $P$. thonningii in Ethiopia in general and South Omo Zone in particular is not adequately documented. The present study was conducted to document the different ethnobotanical uses of $P$. thonningii and the associated indigenous botanical knowledge of the local community and to identify the management practices, and threats to its sustainability in South Omo Zone. The research answers various questions about the uses of $P$. thonningii, influence of demographic factors of the local community on the indigenous and local knowledge, uses, and threats to the sustainability of $P$. thonningii.

\section{Materials and methods \\ Descriptions of the study area}

This study was conducted in the arid and semi-arid areas of the South Omo Zone, southern, Ethiopia (Fig. 1). The South Omo zone is one of the 13 zones found in the Southern Nations, Nationalities, and People's Regional State of Ethiopia. In the zone, there are eight districts, and the zone town is Jinka. The study districts, Benna-Tsemay (Key Afer) and Hamer (Dimeka), are located at about 739 and $839 \mathrm{~km}$ from the capital city of Ethiopia, Addis Ababa, respectively. BenaTsemay District is located at $5^{\circ} 03^{\prime}$ to $5^{\circ} 34^{\prime} \mathrm{N}$ and $36^{\circ} 33^{\prime}$ to $37^{\circ} 03^{\prime} \mathrm{E}$ with altitude ranging from 500 to 2000 m.a.s.l. and Hamer District is located between $4^{\circ} 31^{\prime}$ to $5^{\circ} 28^{\prime} \mathrm{N}$ and $36^{\circ} 09^{\prime}$ to $36^{\circ} 53^{\prime} \mathrm{E}$ with altitude ranging from 381 (Kizo-Baze plain) to 2084 m.a.s.l (Buska-Ale mountain). The study districts cover a total land area of $9496 \mathrm{~km}^{2}$ (Hamer $=$ $5742 \mathrm{~km}^{2}$ and Benna-Tsemay $=3754 \mathrm{~km}^{2}$ ).

The greater proportion of the study area is characterized by arid and semi-arid climatic condition. According to the agroecological map of the Ethiopian Institute of Agricultural Research (EIAR [20], the agroecology of the study Kebeles (subdistricts) of Benna-Tsemay District is categorized as warm humid lowlands $\left(\mathrm{H}_{2}\right)$ and the study Kebeles of Hamer District are categorized as warm semi-arid lowlands $\left(\mathrm{SA}_{2}\right)$.

The rainfall pattern of both districts is bimodal. The average annual precipitation of the Benna-Tsemay district was $933 \mathrm{~mm}$ and the average annual temperature was $20.7^{\circ} \mathrm{C}$. The dry season occurred from the beginning of December to the end of February. The long rainy period which is the cropping season occurs from the end of March to the beginning of June and the short rainy season, which is important only for pasture, occurs between October and November. The average monthly maximum temperature of the warmest month is $30.2{ }^{\circ} \mathrm{C}$ 


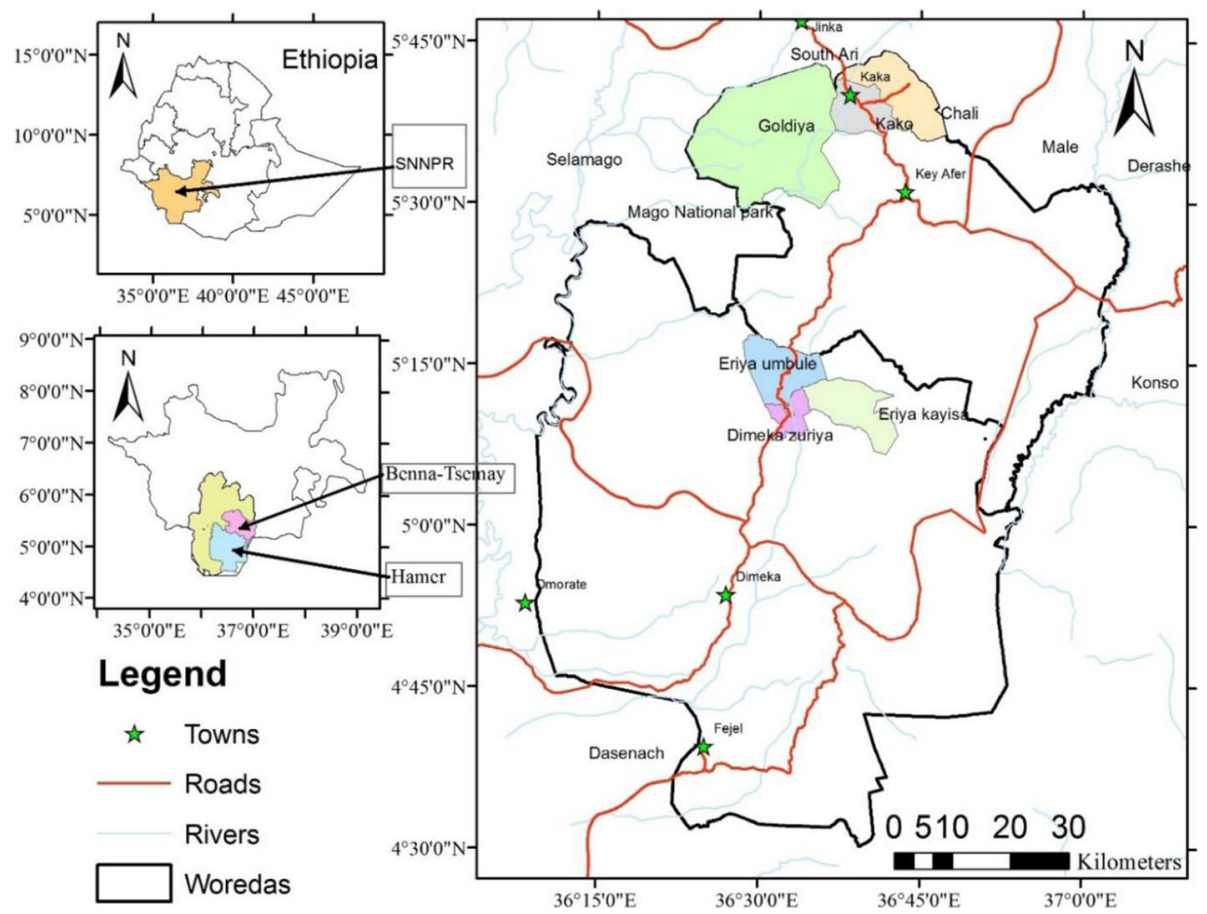

Fig. 1 Map of Ethiopia showing the location of the study area, Hammer and Benna-Tsemay Districts in South Omo Zone, southern Ethiopia

and the average monthly minimum temperature of the coldest month is $12.3{ }^{\circ} \mathrm{C}$ (Fig. $2 \mathrm{~A}$ ).

The average annual precipitation of the Hamer District was $754 \mathrm{~mm}$ and the average annual temperature was 22.9 ${ }^{\circ} \mathrm{C}$. The dry season occurred from mid-November to the beginning of March. The long rainy season occurs from the end of March to May and the short rain season is from the end of September to the end of October. The average monthly maximum temperature of the warmest month is $33{ }^{\circ} \mathrm{C}$ and the average monthly minimum temperature of the coldest month is $14.1{ }^{\circ} \mathrm{C}$ (Fig. 2B). The climate of Hamer is relatively drier than Benna-Tsemay.

The vegetation of the study area belongs to the types known as Acacia-Commiphora woodland and Combretum-Terminalia woodland and wooded grassland [21]. Most of the pastoral and agro-pastoral communities of the study area rely mainly on dry forest resources for livestock fodder, income, food, and medicine. The majority of the communities in Benna-Tsemay District belong to Benna and Tsemay ethnic groups. The human population of the District was 55,590 [22]. However, the current (2018) report from Benna-Tsemay district agricultural bureau shows 72,749 (36,262 male and 36,487 female) (Key-Afer, Agriculture Bureau, unpublished report). The majority of the communities in Hamer District belongs to the Hamer ethnic group. The population of the District was 46,129 [22]. However, the current (2018) report from Hamer district agricultural bureau shows 78,545 (40,122 male and 38,423 female) (Dimeka,
Agriculture Bureau, unpublished report). Pastoralism and agropastoralism are the two main livelihood options in the study area. The livelihoods of these pastoralist communities are mainly rearing of livestock, goats, and sheep and use of their products and the agropastoralists are dependent on both livestock products and crop cultivation. There is limited cereal crop production in Hamer and the people collect and use some wild edible plants [23]. Their main source of income was from the sale of livestock, which was followed by the sale of honey [24]. Food insecurity is a common problem in the study area caused by complex factors such as frequent and extended drought, degradation of natural resources, lack of appropriate technologies, and unpredictable climatic conditions which reduces livestock and plant productivity; this threatens the livelihoods of the pastoral and agro-pastoral communities [24, 25]. Mobility and collection of wild foods is the coping mechanisms to climate variability and food insecurity in the study area [23, 24, 26-28].

\section{Sampling and informant selection}

A reconnaissance survey was first conducted in May 2018 to gain an overview of the availability, distribution, and consumption practice of $P$. thonningii. From the eight districts of the South Omo Zone, two districts (Benna-Tsemay and Hamer) were selected considering their difference in agroecology and presence of at least two major ethnic groups (Benna and Hamer ethnolinguistic communities) and occurrence of $P$. thonningi was 


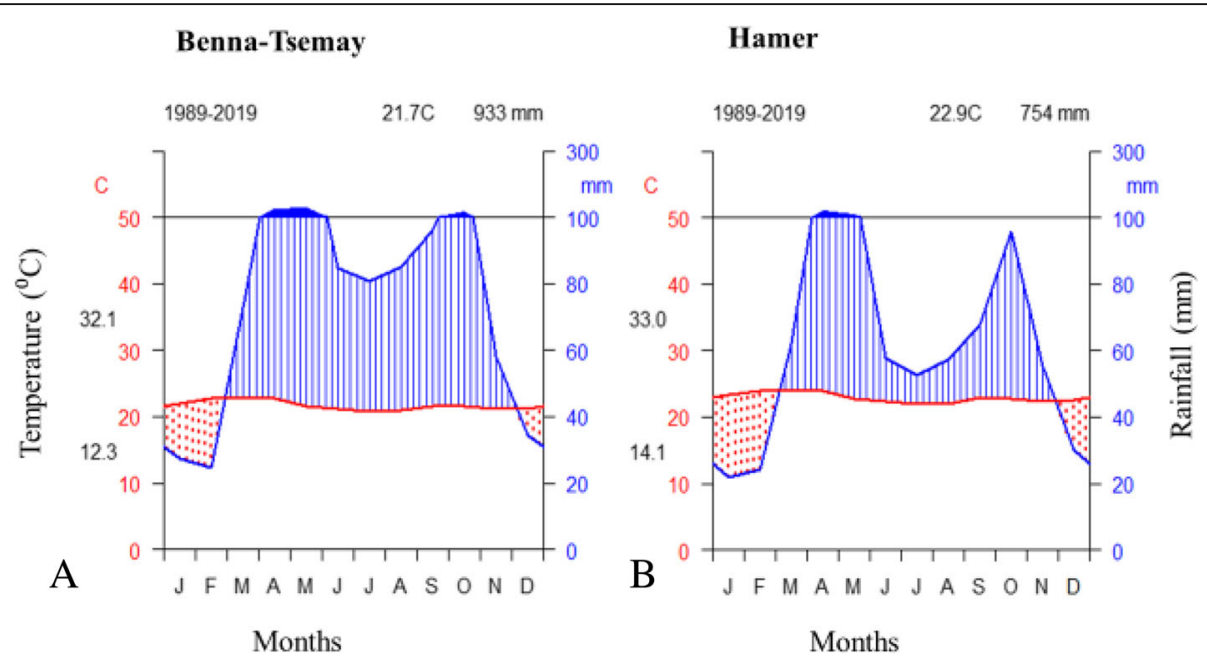

Fig. 2 Climate diagram of the study district showing rainfall distribution and temperature variation from 1989 to 2019 [Data source: Centre for Environmental Data Analysis (Harris \& Jones, 2019)]

taken as criteria for inclusion of kebeles in the study. A discussion was made with both Benna-Tsemay and Hamer district administrators, environment protection, forest, and climate change officers, agricultural development agents and community elders. Following this, field observation was made jointly with field assistants and agricultural development agents to select Kebeles and to check the availability, distribution, and accessibility of $P$. thonningii within the study area. The data collected through this activity helped to purposively select six sample Kebeles (three from Hamerspeaking and three from Benna speaking districts).

The sample size was determined following the standard procedure of Cochran's sample size formula indicated in Kotrlik and Higgins [29]. Consequently, the sample sizes for the two districts were determined separately based on the total number of households in each district $(11,118$ Benna and 9,225 Hamer), and finally, the proportionally calculated manageable sample size for Benna-Tsemay (34 households) and for Hamer (33) was used. To make the number of the household involved in the interview equal in the two districts and in each Kebele, a total of 36 households from each district and 12 households from each Kebele were selected to make an overall total of 72 households. Informants were stratified by gender and relative socio-economic status as low wealth and medium-high wealth status households based on the information obtained from local authorities (agricultural development agents and Kebeles administrators). The wealth status of households in each Kebele was assessed by the district food security desk following the criteria set by Ministryof-Agriculture [30], and the list of poor household who benefits from Productive Safety Net program was given to the Kebele food security task force. The 72 general informants were identified by taking one household informant from each stratified randomly identified household and two key informants from each kebele were purposively selected making a total of 84 informants. Informant sampling approach was following Martin [31] and Alexiades [32]. Thus, out of the 84 informants, 72 (12 informants $\times$ 3 Kebeles $\times 2$ ethnic groups) were general informants selected randomly by a lottery method from the stratified households to give equal chances. The other 12 informants (from 2 ethnic groups $\times 3$ Kebeles $\times 2$ key informants) were key informants selected purposively based on the recommendations from local authorities and elders, confirmed to be knowledgeable about $P$. thonningii and volunteered to participate in the study.

\section{Data collection}

The ethnobotanical data were collected using a structured interview, semi-structured interview, and direct field observation and focus group discussions [31, 33]. The structured interview was based on fixed questions and was mainly used for the collection of local knowledge. The structured questionnaire was also documented by interviewing informants using the Open Data Kit (ODK collect version 1.15.1), an application loaded on a smartphone. Each interviewee was asked the same questions independently without contacts or sharing information with the other informants or with the target population. The semi-structured interview was conducted based on a checklist of questions and both the structured and semi-structured interviews were prepared in English and translated to the local languages (Benna and Hamer) by a proficient local translator. The structured questionnaire is composed of closed questions while the semistructured questionnaire had open-ended questions. Informants were allowed to raise their own points during the interview, not necessarily as responses to questions. The interviewer probed deeper by asking additional questions whenever interesting information or ideas were sensed. 
Guided field walk procedure was followed to collect and record voucher specimens of plants found near/under $P$. thonningii in the selected Kebeles jointly with a field assistant and a translator. Field assistants were selected based on their willingness, ability to walk long distances, general plant knowledge in local name, and capability of translating both ways. The field observation created an opportunity to make a note of the relationship of P. thonningii with other species and other features of the study area.

Six focus group discussions (FGDs) were conducted for crosschecking and verification of the information. Accordingly, the FGDs were undertaken in groups of six in each of the selected Kebeles. The discussion was conducted with key informants, farmers, Kebele administrator, and agricultural development agents, mediated by the researcher. Information collected through focus group discussion is important to triangulate the ethnobotanical data collected through the structured and semi-structured interviews.

\section{Data analyses}

Statistical Package for Social Sciences (SPSS) Version 26.0 was used to analyze ethnobotanical data. A Pearson's chi-square test was used to detect (at $P<0.05$ ) the relationship of the ethnobotanical knowledge held by respondents between different ethnic background, gender, wealth status, age groups, educational level, and Kebeles, regarding the use categories, consumption practice, and attitude of the respondents to conserve the species, and also used to detect the relationship between the different age groups of low- and mid-high wealth status respondents who were involved in the collection and consumption of the fruit. Ethnobotanical ranking methods were employed to analyze the most preferred use of $P$. thonningii and the most destructive threats to it. Direct matrix ranking was carried out to rank the most preferred use of $P$. thonningii in the study area. The 12 key informants were requested to compare the uses of $P$. thonningii based on their preference and importance to the community. Each key informant arranged the uses according to personal preference, perceived importance to the community on a 0 to 5 scale with $0-$ no value, and 5-the highest value. The12 key informants were requested to rank the uses of $P$. thonningii. Pair-wise ranking was employed to determine the degree of destructive activities or threats to $P$. thonningii on a scale of 0 to 5 with 0 -not destructive, and 5-the most destructive. Finally, the given numbers were summed up for all key informants, giving an overall rank in the manner shown by Martin [31]. Then, the highest scores for use diversity ranking were considered as the most preferred use of $P$. thonningii to the local people and the highest scores for threats were considered the most destructive threats to $P$. thonningii.

\section{Results}

\section{Demographic characteristics of Informants}

A total of 84 (72 general and 12 key) informants were involved in the ethnobotanical study of Piliostigma thonningii and 6 individuals in each kebele participated in the focus group discussions for triangulation of the collected information. The proportions of male and female informants were equal in number $(42,50 \%$ each). All the interviewed informants were aged 18-78 years and classified into four age groups based on the perception/cognition of informants [34], demographic structure, and motivation of households [35, 36]. Fourteen percent were 18-30 years old, $35 \%$ were $31-45$ years old, $45 \%$ were from 46 to 60 years old, and the remaining $6 \%$ were $61-78$ years old. Respondents were from different educational backgrounds and classified following Ethiopian education system 4-4-22 (grades 1 to 4 , grades 5 to 8 , grades 9 to 10 , and grades 11 to 12). Eighty percent of the respondents were illiterate, $1 \%$ able to read and write, and the remaining $8 \%$ and $11 \%$ were from grades 1 to 4 and 5 to 8 , respectively (Table 1 ).

\section{The multiple uses of $P$. thonningii}

The results of the study show that $P$. thonningii is a multipurpose tree used by the local communities for various purposes. Based on the consensus points of the focus group discussions, $P$. thonningii is recognized for its contribution to people's livelihoods in many different ways. Both the Benna and Hamer ethnic groups use $P$. thonningii for multiple purposes. It provides various functions including

Table 1 Demographic characteristics of informants

\begin{tabular}{|c|c|c|c|c|c|c|c|c|c|}
\hline \multirow{2}{*}{$\begin{array}{l}\text { Age } \\
\text { groups }\end{array}$} & \multicolumn{4}{|c|}{ Gender } & \multirow{2}{*}{$\begin{array}{l}\text { Educational } \\
\text { status }\end{array}$} & \multicolumn{4}{|c|}{ Gender } \\
\hline & Male & Female & Total & $\%$ & & Male & Female & Total & $\%$ \\
\hline $18-30$ & 7 & 5 & 12 & 14 & Illiterate & 30 & 37 & 67 & 80 \\
\hline $31-45$ & 16 & 13 & 29 & 35 & Read and write & 0 & 1 & 1 & 1 \\
\hline $46-60$ & 14 & 24 & 38 & 45 & Grade 1 to 4 & 4 & 3 & 7 & 8 \\
\hline $61-78$ & 5 & 0 & 5 & 6 & Grade 5 to 8 & 8 & 1 & 9 & 11 \\
\hline Total & 42 & 42 & 84 & 100 & & 42 & 42 & 84 & 100 \\
\hline
\end{tabular}


economic and ecological functions such as provision of shade, food, fodder, soil fertility, provision of firewood, medicine, rope (cordage), Borketa (traditional multipurpose material used as a stool and head support), construction of huts, beehives, fences, and preparation of farm implements. Almost all respondents of both districts widely expressed that they use P. thonningii for firewood and shade. About $92 \%$ of the respondents confirmed that they eat the seeds and $69 \%$ verified its use as fodder for livestock, and $49 \%$ for making Borketa and other uses as indicated in Fig. 3.

The Hamer people predominantly use this species as a source of food (98\%), fodder (83\%), fence (36\%), and for building huts (24\%) as compared to the Benna ethnic group who reported using it predominantly for making Borketa (52\%), rope (55\%), chair (50\%), timber $(24 \%)$, beehives $(26 \%)$, and farm implements $(40 \%)$. All the uses of the species reported in the two districts are given in Fig. 3. However, the use of $P$. thonningii for fuelwood (100\%), shade $(100 / 98 \%)$, soil fertility $(29 / 26 \%)$, and axe handle $(19 / 17 \%)$ were comparable between the two ethnic groups. Twenty-four percent of Benna respondents indicated that they use $P$. thonningii for timber while it is not known as a timber tree in Hamer. Two percent of Hamer respondents indicated that they use it to treat ailments, while the Benna respondents did not indicate any use of it for medicinal purposes.

There is a significant relationship between the age of respondents and their ethnobotanical knowledge of $P$. thonningii $\left(\mathrm{X}^{2}=273.6, \mathrm{df}=42, P<0.0001\right)$.
Older age respondents know more about the uses of $P$. thonningii than younger age respondents. There is no significant $(P<0.05)$ relationship between the ethnic groups, gender, wealth status, and educational level of the respondents regarding their knowledge on the uses of $P$. thonningii. The different use categories in each Kebele (Table 2) was analyzed using Pearson's chi-square test and the result shows that there is a significant association $(P<0.05)$ between Kebeles in the ethnobotanical knowledge of use categories $\left(\mathrm{X}^{2}=107.4, \mathrm{df}=70, P<0.003\right)$.

\section{The contribution of $P$. thonningii as a source of food}

The majority of the respondents (98\% Hamer and $86 \%$ of Benna) indicated that they use P. thonningii as a source of food and consume the fruit during the normal time and during periods of famine to ensure food security. A study by Assefa and Abebe [4] shows that $P$. thonningii is used as a source of food and the consumption of wild food plants in the study areas ranked second as a coping mechanism for surviving during a famine period. Recurrent drought and shortage of food are serious problems of these agropastoral communities. In addition to household consumption, it provides an opportunity to supplement household incomes by selling the edible fruits when there is shortage of food [4]. The fruit ripens in December to February depending on the availability of rainfall. When the brown pod cracks and the seeds shatter away, the pulp surrounding the seeds is eaten raw mainly by children as a snack or as emergency food (Fig. 4).

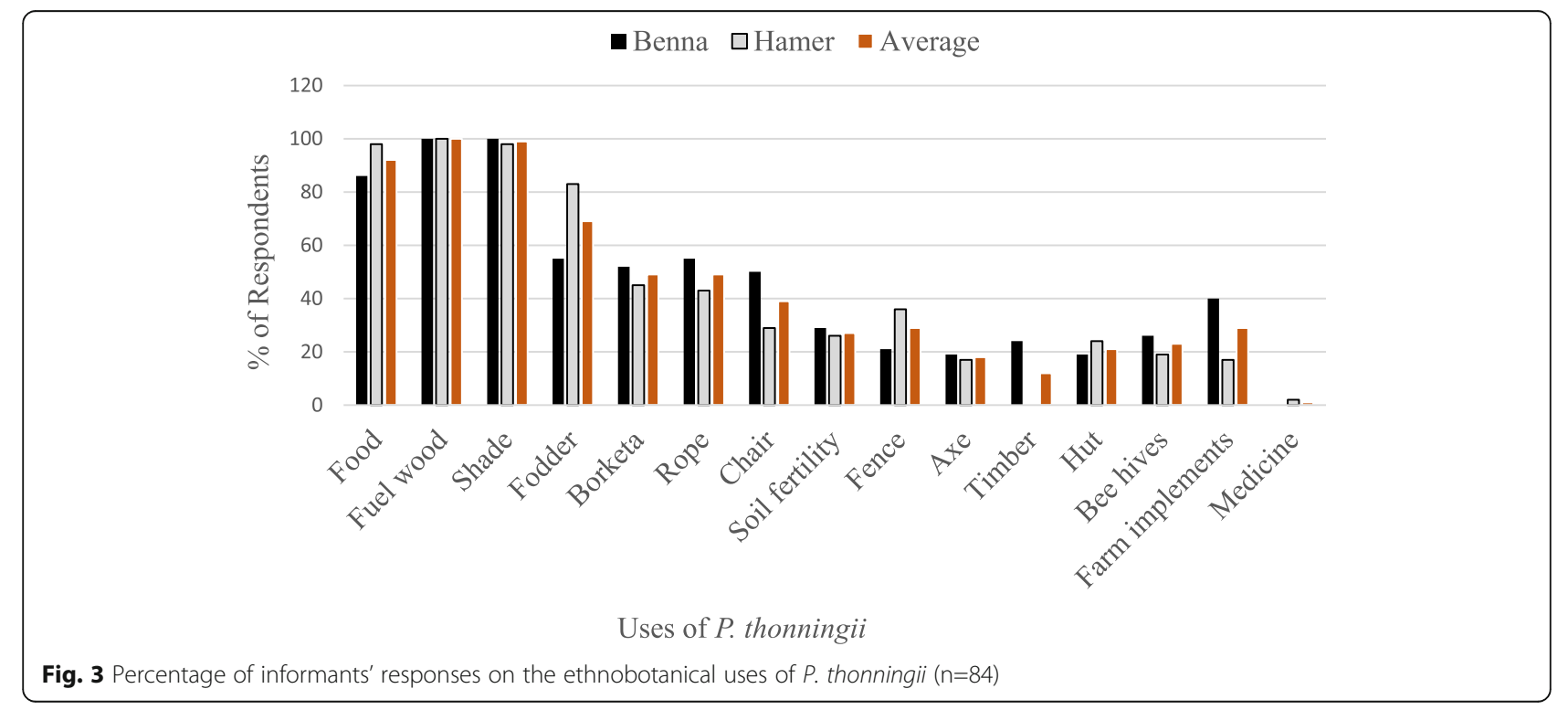


Table 2 The different use categories of $P$. thonningii in each Kebele

\begin{tabular}{|c|c|c|c|c|c|c|c|c|c|c|c|c|c|c|c|}
\hline \multirow[t]{2}{*}{ Kebele } & \multicolumn{15}{|c|}{ Use categories } \\
\hline & $\mathrm{F}$ & Fw & Sh & Fd & B & $\mathbf{R}$ & $\mathrm{Ch}$ & Sf & Fn & A & $\mathbf{T}$ & $\mathrm{H}$ & $\mathrm{Bh}$ & $\mathrm{Fi}$ & $M$ \\
\hline Kako & 12 & 12 & 12 & 11 & 1 & 6 & 0 & 2 & 0 & 0 & 0 & 1 & 0 & 0 & 0 \\
\hline Goldiya & 12 & 12 & 12 & 12 & 10 & 9 & 6 & 4 & 2 & 1 & 0 & 0 & 1 & 2 & 0 \\
\hline Cali & 6 & 12 & 12 & 4 & 5 & 4 & 8 & 0 & 1 & 1 & 3 & 1 & 3 & 3 & 0 \\
\hline Dimeka zuriya & 11 & 12 & 12 & 5 & 3 & 0 & 2 & 0 & 3 & 1 & 0 & 4 & 2 & 1 & 1 \\
\hline Eriya Umbule & 12 & 12 & 12 & 12 & 9 & 6 & 2 & 3 & 1 & 0 & 0 & 0 & 0 & 0 & 0 \\
\hline Eriya Kayisa & 12 & 12 & 11 & 12 & 4 & 5 & 2 & 2 & 5 & 0 & 0 & 0 & 0 & 0 & 0 \\
\hline
\end{tabular}

NB: $F$ food, $F w$ fuelwood, Sh shade, $F d$ fodder, $B$ Borketa, $R$ rope, $C h$ chair, $S f$ soil fertility, $F n$ fence, $A$ axe, $T$ timber, $H$ hut, $B h$ beehives, Fi farm implement, $M$ medicine

\section{Genders and age groups that collect/consume the fruits of $P$. thonningii}

The edible part (fruit) is collected from the grazing lands and farmlands and consumed raw by all community members (children, adults, and elders) during normal times and times of famine. However, $89 \%$ of the respondents reported that children were involved in the collection and consumption of the fruit while only $67 \%$ of adults and $6 \%$ of elders collect and consume $P$. thonningii fruits. There is no difference in the collection/consumption of the fruit between gender of the same age groups.

Respondents from mid-high wealth status households replied that children were involved more in the collection and consumption of the fruit than adults and elders. However, the low wealth status households replied that there is no difference in the collection and consumption of the fruit among the different age groups of poor families. The chi-square test results of the different age groups and wealth classes of informants who were involved in the collection and consumption of the fruit shows that there is a significant $\left(\mathrm{X}^{2}=5.063, \mathrm{df}=1, P<\right.$ 0.024) relationship among the respondents of low wealth status and mid-high wealth status respondents, indicating the former group consumes more. On the other hand, households in both wealth categories reported that there is no difference in the collection and consumption of the fruit between adults and elders of both low and mid-high wealth status households.

The Pearson's chi-square test results regarding the frequency of consumption practices of respondents showed that there is a significant $(P<0.05)$ association between ethnic groups $\left(\mathrm{X}^{2}=8.87, \mathrm{df}=2, P<0.012\right)$, age $\left(\mathrm{X}^{2}=\right.$ $13.67, \mathrm{df}=6, P<0.034)$, and wealth status $\left(\mathrm{X}^{2}=11.33\right.$, $\mathrm{df}=2, P<0.003)$, whereas gender and educational levels did not show significant association at $P<0.05$. Members of the Hamer ethnic group have a strong attachment and hence consume the fruits of $P$. thonningii than the Benna ethnic group and poor households consume more than the rich households. However, there is no significant difference between the Kebeles in the frequency of the consumption of the fruit. The consumption of the
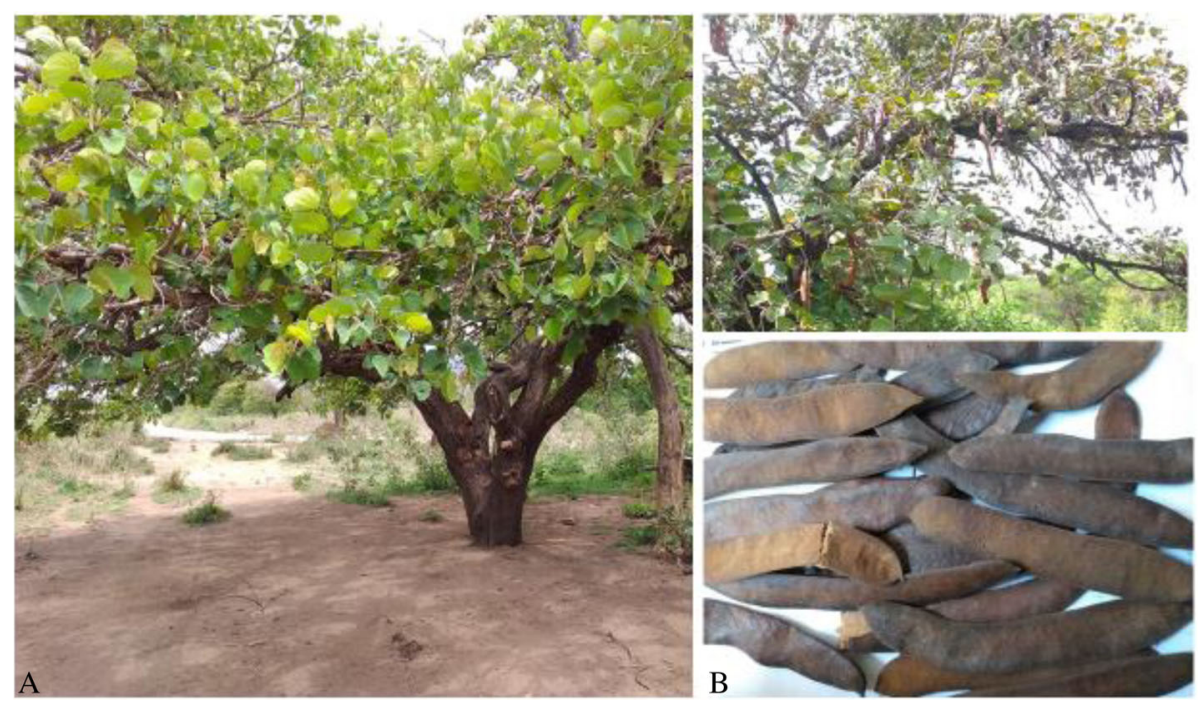

Fig. 4 Whole tree of $P$. thonningii $(\mathbf{A})$ and its ripened fruits (B) 
fruits does not have a complex negative side effect, though $17 \%$ of the respondents reported that they experienced side effects, such as stomach aches, loss of appetite, and constipation, while $83 \%$ of the respondents did not complain of any side effect as a result of consumption of $P$. thonningii fruits.

\section{The role of $P$. thonningii as a source of livestock feed}

The use of $P$. thonningii as livestock feed is common in both (Benna-Tsemay and Hamer) communities. The majority of the respondents $(83 \%)$ reported that they use $P$. thonningii as a source of feed for their livestock. However, some $(17 \%)$ of the respondents replied that they do not use it as livestock feed. All of the respondents of both study areas reported that $P$. thonningii is used as a preferred livestock feed both during times of feed availability and during the dry season. The browsed parts of P. thonningii are mainly seeds, fruits (pod), and leaves, especially the shoot and young leaves are copiously consumed by animals. The majority of the respondents (83\%) indicated that seeds and fruits (pods) are the most consumed parts than any other parts. However, $69 \%$ of the respondents replied that leaves are also consumed by livestock (cattle, goats, and sheep). Small branches are also lopped as dry season fodder for goats and the branches are used to reinforce fences.

Respondents of both districts reported that different livestock types (cattle, goats, and sheep) consume the parts of $P$. thonningii. The consumption of $P$. thonningii by cattle, goats, and sheep depends on the availability of feeds. The majority of respondents reported that it is preferred and consumed by cattle (83\%) and goats $(80 \%)$, and few respondents replied that it is consumed by sheep (15\%).

\section{Agricultural values of $P$. thonningii}

Respondents revealed that $P$. thonningii is used as an agroforestry tree to improve agricultural productivity. Almost all of the respondents (100\% of Benna and 97\% of Hamer) reported that they use the species as a shade tree for their crops and animals and 17\% of Benna and $14 \%$ of Hamer respondents reported that soil under and near $P$. thonningii is moist and fertile. They also use the tree for making farm implements; $40 \%$ of Benna and $17 \%$ of Hamer ethnic groups reported that they use the species to make different farm materials. Respondents explained why they prefer to cultivate crops under $P$. thonningii where $88 \%$ of the respondents reported that they cultivate crops near/under $P$. thonningii by saying that it controls the temperature and keeps the soil moist, $74 \%$ of the respondents reported that it provides good shade for their crops and animals, and the other $29 \%$ of the respondents reported that it makes the soil fertile.
During the field survey, the researcher observed and recorded different herbaceous and woody plant species growing under/near (up to $1 \mathrm{~m}$ radius outside the tree canopy) $P$. thonningii trees that added to 29 species distributed in 18 families. This finding indicates that $P$. thonningii creates a conducive environment for establishment and perpetuation of different plant species belonging to different families under its canopy or near it. The woody species constituted 69\% (45\% shrub, 24\% tree species), herbs constituted about $20 \%$, and climbers constituted $10 \%$. Further analysis of the data showed that 7 (25\%) species belong to the family Fabaceae, two species each to Anacardiaceae, Euphorbiaceae, Rubiaceae, Rutaceae, and Tiliaceae and a single species each in the remaining 12 families (Appendix 1). Many of the characteristics of $P$. thonningii showed that it is an ideal agroforestry tree.

The results of the study further showed that members of the local community cultivated different crops near/ under $P$. thonnongii including maize (Zea mays L.), sorghum (Sorghum bicolor L.), cowpea (Vigna unguiculata (L.)), Teff (Eragrostis tef (Zucc.)), pigeon pea (Cajanus cajan (L.)), finger millet (Eluesine coracana (L.)), cabbage (Brassica spp.), groundnut (Arachys hypogea L.), potato (Solanum tuberosum L.), tomato (Lycopersicon esculenta L.), pepper (Capsicum annuum L.), and onion (Allium cepa L.). The responses of the majority of the respondents showed that the crops most abundantly and commonly cultivated under/near $P$. thonningii are maize (95\%), sorghum (94\%), and cowpea (45\%) (Fig. 5).

\section{The role of $P$. thonningii as a source of fuel and other uses}

The results of the study show that $P$. thonningii is used as a source of fuel, household materials, and other uses. The woody part of the plant is used as a source of firewood, for making Borketa, hut, beehives, chair, fence, axe handles, and timber. Regarding firewood collection, all $(100 \%)$ of the respondents from both districts agreed that they use the wood as a source of fuel, $49 \%$ of the respondents reported that wood is used for making household materials such as Borketa, a traditional multipurpose material used as a stool and head support (the structure of Borketa is found in dryad data repository); $39 \%$ for chair; $29 \%$ for fencing; $23 \%$ for making beehives; $21 \%$ for making huts; $29 \%$ for farm materials; $18 \%$ for axe; and $12 \%$ for timber. About $49 \%$ of the respondents reported that the inner layer of the bark is used to make rope and $1 \%$ of the respondents reported that the bark is used as traditional medicine for the treatment of liver disease through fumigation.

The results of direct matrix ranking, which was carried out to evaluate the multipurpose uses of $P$. thonningii and their relative importance to the local 


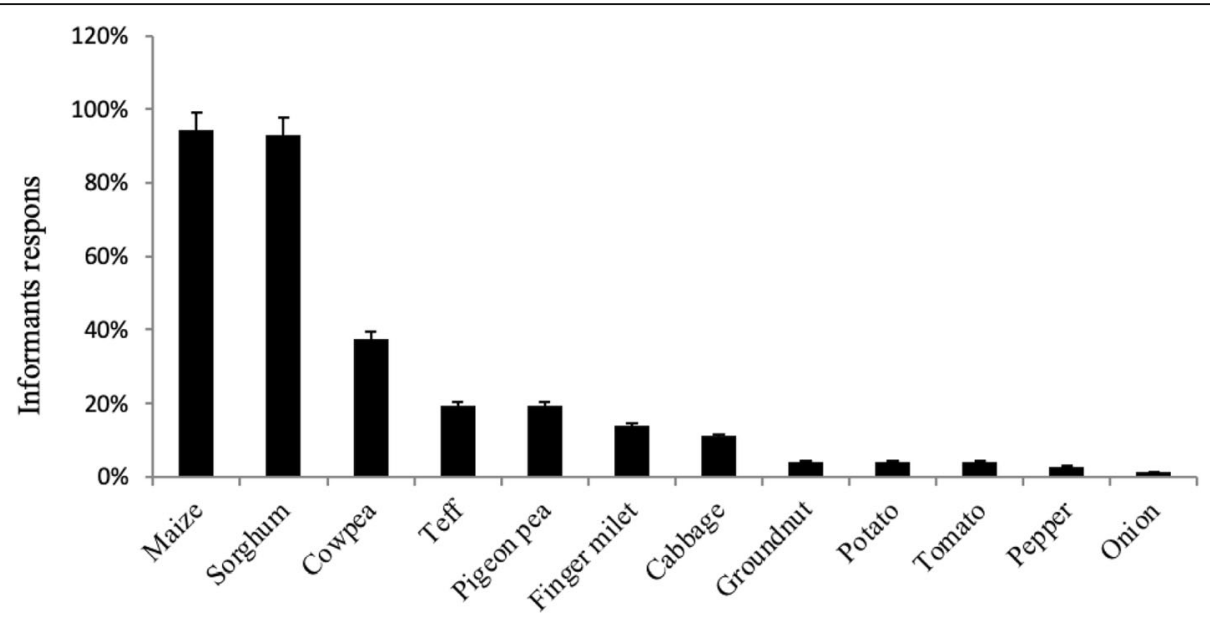

Crops grow under $P$. thonningii

Fig. 5 Percentage of farmers' response on the type of crops grown under/near P. thonningii in Benna-Tsemay and Hamer districts ( $\mathrm{n=84}$ )

people, showed that fodder, food, and firewood ranked in the 1st, 2nd, and 3rd places respectively. And the remaining uses of $P$. thonningii as a shade tree, agricultural value, fencing, making household and farm materials, beehives, and medicine take the ranks from 4 to 9 respectively (Table 3). This shows that the local people use $P$. thonningii mainly for fodder, food, and fuelwood; however, they also use it for different purposes, indicating that it is a multipurpose tree.

The status of $P$. thonningii in the study area

All respondents from Benna and $45 \%$ of the respondents from the Hamer District reported that the abundance of $P$. thonningii has decreased while the other $45 \%$ of respondents from the Hamer District replied there is no difference in abundance as observed over time and while a minority (10\%) of the respondents from Hamer District felt that the abundance of $P$. thonningii has increased in the past 10 years (Fig. 6).

\section{Threats to the sustainability of $P$. thonningii}

All respondents of Benna and the slight majority (55\%) in Hamer reported that the sustainability of $P$. thonningii is threatened by some unfavorable factors. However, $45 \%$ of Hamer respondents replied that there are no threats to the sustainability of $P$. thonningii. According to the information from respondents and participants of the focus group discussion, the main threatening factors to $P$. thonningii are agricultural expansion, firewood collection, overgrazing, harvesting for construction of fences, use for farm and household materials, and charcoal production. Based on this

Table 3 Direct matrix ranking of the use preferences of $P$. thonningii by 12 key informants

\begin{tabular}{|c|c|c|c|c|c|c|c|c|c|c|c|c|c|c|}
\hline \multirow[t]{2}{*}{ Uses } & \multicolumn{14}{|c|}{ Key informants } \\
\hline & $\mathrm{K} 1$ & $\mathrm{~K} 2$ & $\mathrm{C} 1$ & $\mathrm{C2}$ & G1 & G2 & D1 & D2 & U1 & U2 & Ky1 & Ky2 & Total & Rank \\
\hline Food & 4 & 3 & 3 & 3 & 4 & 4 & 3 & 3 & 4 & 3 & 4 & 4 & 42 & 2 \\
\hline Shade & 3 & 3 & 2 & 2 & 3 & 3 & 2 & 3 & 3 & 3 & 3 & 2 & 35 & 4 \\
\hline Fodder & 4 & 4 & 4 & 4 & 5 & 4 & 4 & 3 & 5 & 4 & 5 & 4 & 50 & 1 \\
\hline Firewood & 3 & 3 & 2 & 4 & 3 & 4 & 3 & 3 & 3 & 4 & 3 & 4 & 39 & 3 \\
\hline Agriculture & 2 & 2 & 3 & 3 & 2 & 3 & 3 & 1 & 2 & 2 & 2 & 0 & 25 & 5 \\
\hline Beehives & 1 & 0 & 2 & 0 & 2 & 1 & 0 & 0 & 2 & 0 & 2 & 0 & 10 & 8 \\
\hline Fencing & 3 & 2 & 0 & 2 & 1 & 2 & 1 & 2 & 2 & 3 & 3 & 2 & 23 & 6 \\
\hline Medicine & 0 & 0 & 3 & 0 & 0 & 0 & 0 & 0 & 0 & 2 & 0 & 0 & 5 & 9 \\
\hline Household \& Farm materials & 1 & 2 & 2 & 1 & 0 & 1 & 2 & 1 & 2 & 1 & 2 & 2 & 17 & 7 \\
\hline Total score & 21 & 19 & 21 & 19 & 20 & 22 & 18 & 16 & 23 & 22 & 24 & 18 & 246 & \\
\hline Kebele average & 20 & & 20 & & 21 & & 17 & & 22.5 & & 21 & & & \\
\hline
\end{tabular}




\section{Decreasing $\square$ Same Increasing}

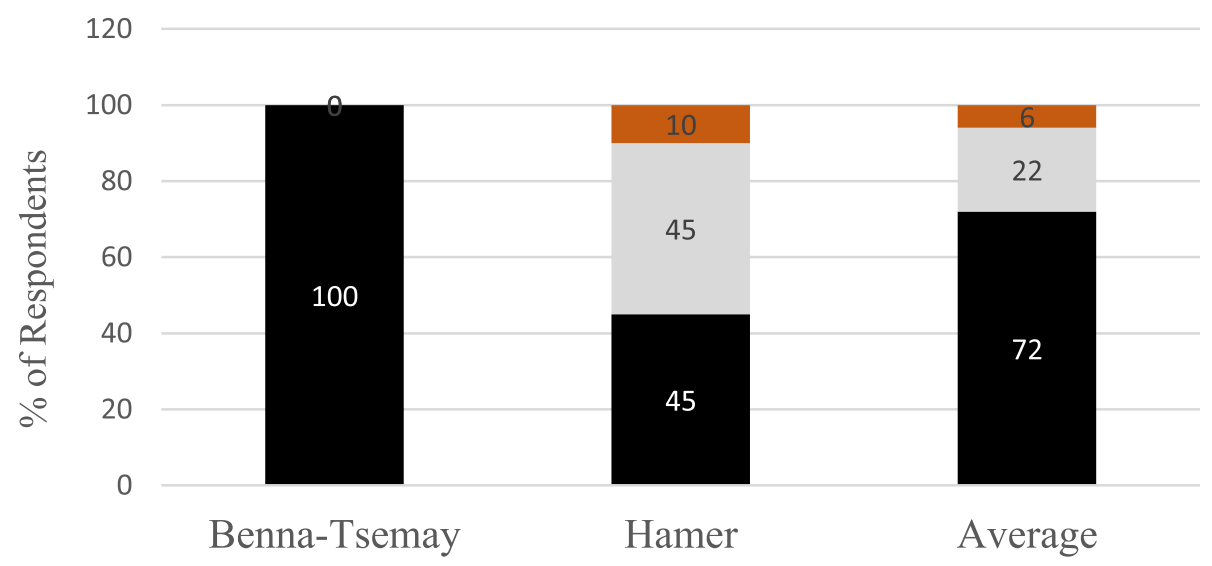

Districts and average value

Fig. 6 Informant's response on the status of $P$. thonningii in the study area (72)

information, the degree of destructive effects of these threats was analyzed using pair-wise ranking. The results suggested that agricultural expansion, firewood collection, fencing, overgrazing, making household and farm materials, and charcoal production are the major factors threatening the continuity of $P$. thonningii in the two districts. Agricultural expansion and firewood collection ranked in the 1st and 2nd places, respectively, indicating that they are the most proximate threatening factors (Table 4).

Traditional management practices and the attitudes of respondents to maintain and conserve $P$. thonningii

Respondents' perceptions about the management and conservation practices of $P$. thonningii showed that $89 \%$ of the low wealth status and $25 \%$ of mid-high wealth status responded that they do not have awareness and interest to manage and conserve $P$. thonningii. However, $11 \%$ of the low wealth status and $75 \%$ of mid-high wealth status respondents expressed that they are interested and willing to maintain and conserve the species. Over half of the male respondents (58\%) and $28 \%$ of female respondents replied that they are interested to maintain a good cover of $P$. thonningii but $72 \%$ of female and $42 \%$ of male respondents were not interested and lack the willingness to manage and conserve. The educational level also affects the perception and willingness to manage and conserve. Most of the respondents had formal education, grades 5 to $8(89 \%)$, and $36 \%$ of the illiterate respondents expressed their interest to maintain and conserve $P$. thonningii but $64 \%$ of the illiterates, all of those who can only read and write, and $11 \%$ of those who had formal education level of grades 5 to 8 do not show an interest to maintain and conserve $P$. thonningii (Fig. 7).

The Pearson's chi-square test results on the perception and attitude of respondents to maintain and conserve $P$. thonningii shows that there is a significant association between gender $\left(\mathrm{X}^{2}=18.36, \mathrm{df}=1, P<0.0001\right)$, wealth status $\left(\mathrm{X}^{2}=83.56, \mathrm{df}=1, P<0.0001\right)$, and educational level $\left(\mathrm{X}^{2}=71.17\right.$, df $\left.=3, P<0.0002\right)$ of respondents. However, there is no statistically significant $(P<0.05)$ association between the different age and ethnic groups regarding their perception and attitude towards the maintaining and conserving of $P$. thonningii. This indicates that men, mid-high wealth status households, and

Table 4 Results of a pair-wise ranking of factors considered threats to $P$. thonningii and their degrees of destructive effects

\begin{tabular}{|c|c|c|c|c|c|c|c|c|c|c|c|c|c|c|}
\hline \multirow[t]{2}{*}{ Threatening factors } & \multicolumn{14}{|c|}{ Respondents of each Kebele } \\
\hline & $\mathrm{K} 1$ & $\mathrm{~K} 2$ & C1 & $\mathrm{C2}$ & G1 & G2 & D1 & D2 & U1 & U2 & Ky1 & Ky2 & Total & Rank \\
\hline Firewood & 4 & 4 & 4 & 4 & 5 & 4 & 4 & 4 & 5 & 5 & 4 & 5 & 52 & 2 \\
\hline Agricultural expansion & 5 & 5 & 5 & 5 & 4 & 5 & 4 & 5 & 4 & 4 & 5 & 4 & 55 & 1 \\
\hline Overgrazing & 2 & 2 & 3 & 1 & 3 & 2 & 1 & 2 & 2 & 2 & 2 & 3 & 25 & 4 \\
\hline Fencing & 3 & 2 & 2 & 3 & 2 & 3 & 2 & 3 & 3 & 1 & 3 & 2 & 29 & 3 \\
\hline Household and Farm materials & 1 & 1 & 1 & 2 & 2 & 1 & 0 & 1 & 1 & 2 & 2 & 1 & 15 & 5 \\
\hline Charcoal & 0 & 0 & 1 & 0 & 1 & 1 & 1 & 0 & 0 & 0 & 0 & 0 & 4 & 6 \\
\hline
\end{tabular}

NB: K Kako, C Cali, G Goldiya, D Dimeka zuriya, U Eriya Umbule, Ky Eriya Kayisa 


\section{- Moderately interested $\square$ Not interested}

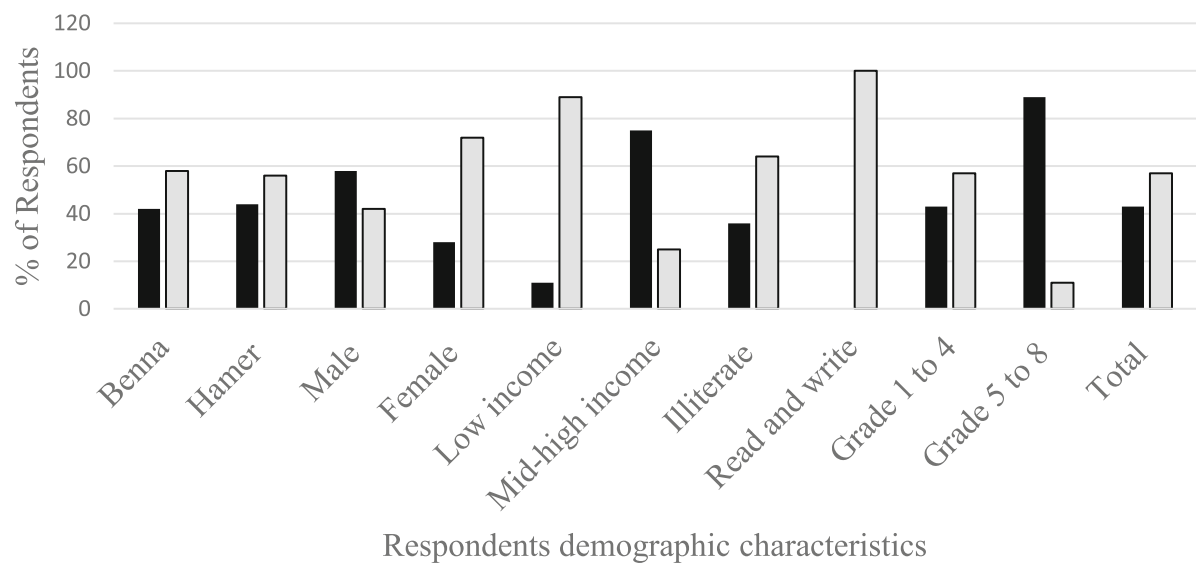

Fig. 7 The attitude of respondent's to maintain and conserve $P$. thonningii (72)

educated people are more knowledgeable and have willingness to maintain and conserve $P$. thonningii than women, low wealth status households, and uneducated community members. The statistical analysis result shows that there is no significant difference between kebeles towards the maintaining and conservation of $P$. thonningii. They manage and conserve the species in their farms and homesteads by avoiding cutting and protecting from livestock damages.

\section{Discussion}

\section{The multiple uses of $P$. thonningii}

The results indicate a strong relationship between the local communities and $P$. thonningii in that the species provides several economic and ecosystem functions in the study area so much that it has become an integral part of the local culture. This shows that there is an intrinsic relationship between humans and their environment and between knowledge about plants and their uses. In this regard, Martin [31], Kacholi [37], and Amjad and Arshad [38] describe the relationship between plants, people, and the environment and the knowledge of local communities about the uses of plants as a source food, medicine, fuelwood, timber, fodder, shade, poles, and habitats for other organisms. Similarly, Demel et al. [39] describe the indirect benefits of wild edible plants such as sources of genetic diversity; encourages agroforestry practice in dry land areas; habitat for different organisms; rehabilitation of degraded lands; and soil and water conservation as well as mitigation and adaptation to climate change. The ethnobotanical knowledge of respondents about $P$. thonningii among the two ethnic groups within and between the different wealth status, gender, and educational level is similar. This indicated that the transfer of indigenous knowledge on the uses of $P$. thonningii within the community is not differentiated by wealth status, gender, and level of education because of the co-existence and similarity of their cultural practices and the pastoralist mode of life. This finding is in line with that of Awas et al. [40] that showed the ethnobotanical knowledge of Berta and Gumuz people of western Ethiopia equated with the age and educational level. The relationship in the knowledge of respondents on the uses of $P$. thonningii among the different age groups showed that older members of the communities were more knowledgeable on the uses of $P$. thonningii as compared to the younger member of the communities. The relationship in the ethnobotanical use of $P$. thonningii between Kebeles associated with the life style of the households, food insecurity, availability of infrastructure, and distance of the Kebeles from the town. For example in relation to food and timber, Cali Kebele was different from others because majority of the people of Cali involved in crop cultivation other than using wild plants. In the use as a fodder, Cali and Dimeka zuriya Kebeles were different from other Kebeles because these Kebeles are relatively near the town and involved in agriculture crop production and use crop residue for their livestock feed. In agreement with this, Bortolotto et al. [41] describe that proximity to urban centers reduces the use of wild plants for various purposes. The Kebeles Goldiya and Eriya Umbule use the tree for making Borketa more than the other Kebeles, because majority of the communities were pastoralist, they move from place to place to find animal feed during drought and use the material as a stool and head support.

\section{Contribution of $P$. thonningii as a source of food}

A study by Teklehaymanot [42] shows that people in semi-arid and arid areas rely more on wild edible plants 
as compared to people in humid and highland regions. This study was conducted in the arid and semi-arid areas of southern Ethiopia where there are harsh environmental conditions. In arid and semi-arid environments drought has a dominant effect on agricultural food production and livestock productivity. In most arid environment, the role of wild edible plants as food security agents has been reported by different authors $[4$, $26,43-45]$. The results of the present study showed that the communities of the South Omo Zone consume $P$. thonnngii as a supplement to staple foods and to fill a variety of food gaps besides fighting food insecurity during period of drought. Similar studies by Guinand and Lemessa [26], Terefe et al. [24]; Addis et al. [23], and Kidane and Kejela [27] indicated that the collection of wild foods is used as coping mechanisms to climate variability and food insecurity. A higher use of wild foods has been linked with greater food security [46]. Thus wild edible plants served as "buffer food" as they had rescued people during floods, drought, and major famines. In agreement with this, the finding of Hidosa et al. [47] and Teklehaymanot [42] indicated that people in semi-arid and arid regions of the Oromia and Afar region survive times of severe hunger by consuming wild edible plants. The fact that the fruit is the edible part of $P$. thonningii and consumed raw has an added advantage as an emergency quick fix facility at critical moments in the daily and annual cycles. This also goes along with the general finding in Ethiopia that the fruit is the dominant parts of wild edible plants $[23,28,45,48,49]$. $P$. thonningii is relevant to household food security to supplement the staple food in normal times, to fill seasonal food shortages, and for fighting poor micronutrient intake or otherwise called hidden hanger [50]. Similar studies in Africa show that the fruit and seeds of P. thonningii are nutritious and contain the primary metabolites like protein, starch, fat, and lignin [11-13, 15]. As reported by Poulton and Poole [51], Awas [52], and Adhikari et al. [53], wild edible plants are nutritionally rich and supply vitamins and micronutrients. In addition to improving food security, the consumption of fruits from trees improves blood circulation, prevents diabetes, and reduces obesity, cancer, and chances of being affected by heart diseases [54]. The finding on raw consumption of the fruits of $P$. thonningii equates to the work of Guinand and Lemessa [26], Balemie and Kebebew [49], Belayneh et al. [55], Teklehaymanot [42], and Dejene et al. [56], indicating fruits of most wild edible trees are consumed raw, not cooked or preserved, suggesting that the fruit is not toxic.

The difference in ethnic background, age, and wealth status of the community has affected the pattern of collection and consumption of the fruit. The mid-high wealth status families tend to see the consumption of the fruit of $P$. thonningii as a sign of poverty, but poor families collect and consume the fruit to mitigate the risks of hunger and make an important part of their daily dietary intake. In agreement with this, Poulton and Poole [51] reported that wild edible plants make many contributions to poor people's livelihoods and most of the disadvantaged and vulnerable peoples of the society mitigate risks using wild food plants. However, in the study area when there is a serious shortage of food affecting both the poor and rich families, all are involved in the collection and consumption of the fruit as explained by informants.

According to mid-high wealth status respondents, children are the main participants in the collection and consumption of the fruit than adults and elders. This is because children can climb up to a tree, collect the fruit while tending cattle in the grazing fields, fetch water, collect firewood, or walk to the fields. On the other hand, adult members of the community mostly spent their time on other daily activities like farming, the market, and other social activities. Moreover elder members of the communities spend most of their time at home and do not have a chance to get and collect the fruit. However, during food shortage adults and even elder members of the community are involved in the collection and consumption of the fruit. In agreement with this, the findings of Guinand and Lemessa [26] and Teklehaymanot and Giday [45] indicated that adults and elders collect and consume the fruit from the wild and over $70 \%$ of the wild edible plants were consumed during times of food scarcity and starvation. In normal times, mainly children and poor families were involved in the collection and consumption of the fruit. This goes in line with the response of low-wealth status households who stated that there is no difference in the collection and consumption of the fruit among the different age groups of poor families.

The consumption of the fruit is sometimes accompanied with some complaints. A few respondents (17\%) reported that excessive consumption of the fruit causes stomach aches, loss of appetite, and constipation and induces thirst. Other than minor complaints and discomforts, $P$. thonningii seeds or other parts of the plant did not cause serious side effects to the majority of the respondents (83\%) even when consumed uncooked. This may be related to the assertion by Nwosu et al. [57] that the level of dietary fiber of $P$. thonningii is quite high when compared with that of most legumes and seeds. Dietary fiber plays an important role in reducing the risk and lowering the incidence of numerous diseases [58]. It prevents constipation and provides other health benefits, such as maintain a healthy weight and lowering the risk of diabetes, heart disease, and some types of cancer. This indicates fiber-rich food is suitable for health and the local people know the 
importance and contribution of wild fruits to their daily dietary ratio as well as alleviating possible health problems such as stomach irritation, stomach aches, and constipation.

\section{The role of $P$. thonningii as a source of animal feed}

The majority of the respondents $(81 \%$ of Hamer and $75 \%$ of Benna-Tsemay Districts) replied that the seeds, fruit (pod), and leaves of $P$. thonningii are consumed by different livestock types. It is an important fodder tree in the study area with the leaves, pods, and seeds being nutritious and preferred by cattle, goats, and sheep. It is browsed directly from the tree or lopped/cut fresh during feeding. The edible parts provide valuable livestock feed under open grazing conditions. This is especially important during the dry season when grazing resource is limited. The use of the parts of $P$. thonningii as livestock feed has been reported in different studies such as Guinand and Lemessa [26], Geta et al. [59], and Ayenew [9]. In agreement with this study, the findings of Jimoh and Oladiji [13], Bekele and Tengnäs [3], Orwa et al. [1], Egharevba and Kunle [11], Chidumayo [10], and Jemiseye et al. [12] revealed that the pods are nutritious and preferred by domestic animals such as cattle and browser wild animal species such as the African elephant and antelopes.

The $P$. thonningii leaf meal has high crude protein content (20.5\%) [57], as compared to other browse trees (like finger millet straw) indicating the potential of this tree leaf to be used as a supplement to improve poor quality feed. In the study area, livestock prefer the young leaf over the matured one in agreement with Nwosu et al. [57] that reported higher crude protein content of $P$. thonningii at the early stage of the leaf than the mature leaf. A similar study on the use of multipurpose fodder trees by Geta et al. [59] indicated that $P$. thonningii leaves are nutritious and improve poor-quality roughage, and are important for livestock production in promoting health, growth, and milk production. The proper use and management of $P$. thonningii is, therefore, essential to realize these potentials.

\section{Agricultural uses of $P$. thonningii}

Integrating $P$. thonningii into the agricultural field and grazing land plays an important role in achieving household food security and in the conservation of other plants. P. thonningii allows good production of crops and creates a suitable microclimate for other plants growing under or near the canopy. The findings of Chidumayo [10] indicated that it is a promising agroforestry tree in sub-Saharan Africa. It is a deciduous tree that undergoes a physiological dormancy and sheds its nitrogen-rich leaves during the dry season, to cope with moisture deficiency. The litter from the shed leaves improves the soil structure and permeability while the retained leaves in the dry season provide shade to conserve the available soil moisture by reducing the evapotranspiration under the tree. The findings of Wood and Burley [60] and Chidumayo [10], which are in agreement with this study, show the role of $P$. thonningii as an excellent shade tree which helps in retaining soil moisture and nutrients. Thus, plants under $P$. thonningii remain green for a longer period in the dry season providing grazing material for both wild and domestic animals. A study by Woldu et al. [61] shows the role of canopy trees like Acacia tortilis and Acacia Senegal in promoting better growth and productivity of agricultural crops and herbaceous species growing under their canopy by creating favorable conditions to the soil nutrient and moisture.

\section{The role of $P$. thonningii as a source of fuel and other uses}

The use of $P$. thonningii as a source of fuelwood, for construction (making huts), for making of household equipment (Borketa, chair, and axe handles), fences, beehives, and timber are widely experienced. In agreement with this, Thulin et al. [2], Bekele and Tengnäs [3], Orwa et al. [1], and Chidumayo [10] reported the suitability of P. thonningii as a source of fuelwood, poles, charcoal, carpentry, construction, to make household mat and farm implements. The utilization of this tree is linked with the daily life activities of the local communities of the study area. In the study area, firewood is the most preferred and affordable domestic fuel for cooking and heating for both rural and urban communities. In agreement with this study, the findings of Gebreegziabher [62] and Eastaugh et al. [63], showed the importance of multi-purpose woody species to increase the supply of fuelwood for rural household consumption and $80 \%$ of rural households use fuelwood as their primary energy source. Similarly in southwestern Ethiopia, fuelwood is the main energy source for the majority of the people [64]. And also, Bekele [65], Gebreegziabher [62], and Mekonnen and Köhlin [66] reported that more than 90\% of households in Ethiopia use biomass fuels (fuelwood, animal dung, and agricultural residues) especially fuelwood as their primary energy source to meet their cooking and heating needs and more (99.9\%) rural households rely on biomass fuels than those in urban areas.

The results of the study showed that $49 \%$ of the respondents reported that the inner part of the stem bark is suitable for making ropes. In the study area, ropes are used for tying the roof of the huts and to make whips for herding goats and cattle. Similarly, Thulin et al. [2], Orwa et al. [1], and Egharevba and Kunle [11] confirmed the use of the inner bark to make ropes/cordage. 
Unsustainable use for making ropes and some other functions become destructive to the species. Therefore, it is necessary to use sustainably without killing the parent tree.

Few respondents (1\%) reported the use of $P$. thonningii for traditional medicinal uses for the treatment of liver disease through fumigation; similarly, a study by Kidane et al. [67] shows that the leaf of $P$. thonningii is used for the treatment of similar diseases. Inversely, a study by Awhin et al. [68] shows that chronic/habitual/recurring consumption of $P$. thonningii may cause liver injury thereby increasing the liver enzyme activity. There is no information regarding its medicinal use in the other parts of Ethiopia; therefore, there is a need for more research on the medicinal uses of $P$. thonningii. The plant is not extensively used for medicinal purposes presumably because there are other medicinal plants more potent than $P$. thonningii preferred by the people of the study area. However, in different African countries (such as Nigeria, Kenya), it is used as a traditional medicine. The different parts (flowers, bark, fruits, roots, leaves, and stems) are used elsewhere to treat various diseases $[1,11-16,18,57,69]$. It is important to document and share the experience to other people elsewhere about the medicinal uses of $P$. thonningii in case they are not aware of it.

\section{The status of $P$. thonningii in the study area}

The abundance of $P$. thonningii is decreasing (72.6\%) mainly due to expansion of agricultural land, firewood collection, overgrazing, and harvesting wood for construction of fences and charcoal production, while the others $(22.6 \%)$ reported that there is no change in the status, because before 10 years the local community used to set bushfire to enhance the re-sprouting of pasture grasses and to control animal exo-parasites (tsetse fly and ticks). Currently, setting bushfire intentionally or inadvertently is prohibited which promotes the reestablishment of woody species while the expansion of agricultural land decimates the tree cover. The effects of the two opposite processes cancel each other and the status of $P$. thoningii appears to remain unchanged. However, $4.76 \%$ of the respondents indicated that the status is increasing due to the prohibition of fire setting. Reilly et al. [70] describes that, after fire setting, there is an increase in species richness of all plants, and Burkle et al. [71] reported that local species richness of forbs was higher in burned landscapes compared to unburned landscapes at the low-productivity site, but lower in burned landscapes at the high-productivity site. The researcher field observation from 2018 to
2020 confirmed that there is a decrease in the status of $P$. thonningii because of the destruction of the habitats. Many of the woodland and grazing lands were converted to agricultural land; in some areas, there is still illegal bushfire to acquire more agricultural land and the awareness of the local community to the conservation of natural resources is limited.

\section{Threatening factors to $P$. thonningii}

$P$. thonningii faces different threats to its continued existence from various human activities. Agricultural expansion, firewood collection, and harvesting for fencing were found to be the most threatening factors. Agricultural expansion is a major threat because nowadays the community of the study area is changing from a pastoral to an agropastoral way of life and that the population is increasing. The suitable habitats for the growth of $P$. thonningii are increasingly threatened by the continued conversion of the woodland and grazing land into farmlands. A study by Assefa and Abebe [4] showed that the community of the South Omo Zone is changing from a pastoral to an agropastoral way of life. In agreement with this study, FAO [72] showed the major cause of deforestation in Ethiopia resulted from the conversion of forested land into agricultural land and other land-use systems, and Dandena [73] explains the effect of agricultural expansion on resource availability in rural areas, thereby decreasing the volume of fruits harvestable for private consumption. During the field observation and group discussion, it was observed that the agricultural development workers and local administrators push the pastoral community to involve in agriculture without selecting appropriate land suitable for agriculture and without consideration of the agroforestry system. And also, both the rural and urban households use firewood predominantly as a domestic fuel including $P$. thonningii. Similar findings were reported by Gebreegziabher [62] who indicated that multi-purpose woody species are important to increase the supply of fuelwood for rural household families. Hence, strategies should be designed to protect and domesticate these plants for future use. There is also harvesting of the tree for various uses such as for fences without protection and hence causing damage.

\section{Traditional management practices and attitude of respondents to maintain and conserve $P$. thonningii}

The attitude and interest of respondents to maintain and conserve $P$. thonningii is different among gender, wealth status, and educational levels. 
Respondents from mid-high wealth status, men, and educated members of the community practice some activities to manage and conserve $P$. thonningii that grow in their farms and homesteads by avoiding cutting and protecting it from livestock damage but there is no direct planting and protection of $P$. thonningii found in their communal land (grazing and woodland). Personal observation also confirmed that $P$. thonningii grow in farmlands, farm boundaries, watershed areas, and homesteads as live fence and shade. This tradition is a good implication of indigenous management strategies for conservation and management of this species. A study by Cao et al. [74] and Kebebew and Leta [75] describes the importance of introducing the preferred wild plants into farm lands and home gardens for the conservation of biodiversity and mitigation of climate change. However, respondents from low wealth status have limited or are not interested to maintain and conserve the species, because most of the low wealth status respondents do not have their own land or have a parcel of their own land. They are using borrowed land, and in such borrowed land, they are not allowed by the owner of the land to plant perennial plants. Therefore, low-wealth status households do not have planting experiences at all, but not only that they lack the willingness to manage and conserve. Similar to this, Ayenew [9] indicates the very low farmers practice to plant and manage the tree. They are constrained by the priority to ensure basic food self-sufficiency in their allocated land and give prior satisfaction to their needs to produce staple food. A similar finding by Poulton and Poole [51] shows poor households lack lands for the cultivation of wild edible fruits and they focus on the cultivation of crops that help them to ensure their basic food requirement on their lands. The other difficulties are the low market values of wild fruits when compared to cultivated fruits, which discourage the growth of fruit by the poor households. This information shows that, as the wealth status increases the attitude of respondents to manage and conserve also increases. Similarly, as the education level increases, the knowledge and attitude to manage and conserve also increases, indicating that educated communities have more knowledge and willingness to maintain, conserve, and plant the tree. On the other side, men have more interest to maintain, conserve, and plant $P$. thonningii than women. In this regard, in the study area, men control and manage the land and participate in tree planting than women; this restricts female participation in planting. As indicated by Gandile et al. [76], the most notable biodiversity conservation practice was the protection of forests using indigenous knowledge. Therefore, it is necessary to incorporate economic and cultural importance in biodiversity assessments and conservation measures, involving local resource users and all stakeholders from different sectors to maintain and conserve the species. The ecological knowledge held by local and indigenous users must be recognized and fully incorporated into management and conservation plan. In agreement with this, Carvalho and Frazão-Moreira [77] describe the importance of local knowledge in plant resources management and conservation. Creating awareness on the importance of wild plants for millions livelihoods among policy makers and across the society involves the community leaders to give proactive, protective orders to community to maintain and protect useful trees.

\section{Conclusion and recommendations}

This study attempted to provide information on the multiple uses of $P$. thonningii besides documenting the traditional knowledge of the local community. In the study area, the pastoral and agropastoral communities use $P$. thonningii for various purposes. There is a good transfer of local traditional knowledge between the communities on the uses of $P$. thonningii. However, it was observed that there is knowledge gap through generations indicating that the youth are less knowledgeable about the uses of $P$. thonningii. Therefore, documentation of the traditional knowledge of the local communities on the uses of $P$. thonningii in the present study area and other parts of the country is very valuable and needs to be scaled-up.

P. thonningii contributes to the nutritional intake of the local communities and helps to ensure food security during the times of seasonal food shortage. Therefore, consideration should be given to $P$. thonningii when strategies are developed to fight food insecurity and to improve rural livelihood systems. It is an excellent fodder tree, used by the pastoral and agro-pastoral communities of the study area to feed their livestock under open grazing conditions. It improves the nutritional content of poor feed quality and the survival and productivity of livestock. It is also used as an excellent agroforestry tree to improve soil fertility, moisture retention capacity, and maintain soil structure in addition to provision of human food, livestock feed and other related uses. The local communities also use it for different purposes, such as source of fuelwood, for construction of huts, making beehives and household utensils (Borketas, chairs, and axe handles). Therefore, it is necessary to integrate it 
into the agroforestry systems and home-garden practices. P. thonningii is less known in its medicinal use as compared to in other African countries. Therefore, it is necessary to undergo more researches on its traditional medicinal value.

The results also showed that the status of $P$. thonningii is decreasing because of the pressures from various anthropogenic factors. The main threatening factors are agricultural expansion, firewood collection, harvesting for fencing, and overgrazing. Thus, there is a need to create public awareness and community-based management. Therefore, it is important to promote $P$. thonningii as a valuable tree to improve household food security, agricultural productivity, and income source of the local communities.

\section{Appendix}

Plant species observed growing under/near P. thonningii tree

\begin{tabular}{|c|c|c|c|c|c|}
\hline No. & $\begin{array}{l}\text { Scientific } \\
\text { name }\end{array}$ & Family & $\begin{array}{l}\text { Local } \\
\text { name } \\
\text { (Benna } \\
\text { Language) }\end{array}$ & $\begin{array}{l}\text { Local name } \\
\text { (Hamer } \\
\text { Language }\end{array}$ & Habit \\
\hline 1 & $\begin{array}{l}\text { Acacia robusta } \\
\text { Burch. }\end{array}$ & Fabaceae & Dhera & Dhera & $\mathrm{T}$ \\
\hline 2 & $\begin{array}{l}\text { Acacia goetzei } \\
\text { Harms }\end{array}$ & Fabaceae & Arke & Arki & $\mathrm{T}$ \\
\hline 3 & $\begin{array}{l}\text { Acacia hockii } \\
\text { De Wild. }\end{array}$ & Fabaceae & Chekanti & Chakanti & Sh \\
\hline 4 & $\begin{array}{l}\text { Acacia seyal } \\
\text { Del. }\end{array}$ & Fabaceae & Pulanti & Fulante & $\mathrm{T}$ \\
\hline 5 & $\begin{array}{l}\text { Acalypha } \\
\text { fruticosa Forssk. }\end{array}$ & Euphorbiaceae & Septi & Septi & Sh \\
\hline 6 & $\begin{array}{l}\text { Adenium } \\
\text { obesum } \\
\text { (Forssk.) Roem. } \\
\text { \& Schult. }\end{array}$ & Apocynaceae & Gurdo & Gurdo & Sh \\
\hline 7 & $\begin{array}{l}\text { Becium } \\
\text { obovatum } \\
\text { (E.Mey.ex } \\
\text { Benth. }\end{array}$ & Lamiaceae & Buranbutso & Butamberohata & $H$ \\
\hline 8 & $\begin{array}{l}\text { Cissus } \\
\text { rotundifolia } \\
\text { (Forssk.) Vahl }\end{array}$ & Vitaceae & Kelle & Kelle & C \\
\hline 9 & $\begin{array}{l}\text { Clematis } \\
\text { simensis Fresen. }\end{array}$ & Ranunculaceae & Gayadenpo & Gayatenpo & C \\
\hline 10 & $\begin{array}{l}\text { Cynodon } \\
\text { dactylon (L.) } \\
\text { Pers. }\end{array}$ & Poaceae & Zersi & Zersi & G \\
\hline 11 & $\begin{array}{l}\text { Dalbergia } \\
\text { lactea Vatke }\end{array}$ & Fabaceae & Zinzek & Zinzeke & Sh \\
\hline 12 & $\begin{array}{l}\text { Entada } \\
\text { abyssinica } \\
\text { Steud. Ex A. } \\
\text { Rich. }\end{array}$ & Fabaceae & Longo & Longo & $\mathrm{T}$ \\
\hline 13 & $\begin{array}{l}\text { Erythrococca } \\
\text { abyssinica Pax }\end{array}$ & Euphorbiaceae & - & Koda & Sh \\
\hline 14 & Euclea & Ebenaceae & Unsi & Kunsi & Sh \\
\hline
\end{tabular}

\section{Appendix (Continued)}

\begin{tabular}{|c|c|c|c|c|c|}
\hline No. & $\begin{array}{l}\text { Scientific } \\
\text { name }\end{array}$ & Family & $\begin{array}{l}\text { Local } \\
\text { name } \\
\text { (Benna } \\
\text { Language) }\end{array}$ & $\begin{array}{l}\text { Local name } \\
\text { (Hamer } \\
\text { Language }\end{array}$ & Habit \\
\hline & racemosa Murr. & & & & \\
\hline 15 & $\begin{array}{l}\text { Gardenia } \\
\text { ternifolia } \\
\text { Schumach. \& } \\
\text { Thonn. }\end{array}$ & Rubiaceae & Gembela & Gembela & $\mathrm{T}$ \\
\hline 16 & $\begin{array}{l}\text { Grewia velutina } \\
\text { (Forssk.) Vahl. }\end{array}$ & Tiliaceae & Bereza & Berez & $\mathrm{T}$ \\
\hline 17 & $\begin{array}{l}\text { Grewia villosa } \\
\text { Will. }\end{array}$ & Tiliaceae & Gergecha & Gergesho & Sh \\
\hline 18 & $\begin{array}{l}\text { Hypoestes } \\
\text { forskaolii (Vahl) } \\
\text { R.Sch. }\end{array}$ & Acanthaceae & Busunta & Busente & $H$ \\
\hline 19 & $\begin{array}{l}\text { Ipomoea } \\
\text { kituiensis Vatke }\end{array}$ & Convolvulaceae & Gali & - & Sh \\
\hline 20 & $\begin{array}{l}\text { Kalancboe } \\
\text { citrina } \\
\text { Scweinfurth. }\end{array}$ & Crassulaceae & $\begin{array}{l}\text { Gaya } \\
\text { dempo }\end{array}$ & Gaya tampo & $\mathrm{H}$ \\
\hline 21 & $\begin{array}{l}\text { Ozoroa insignis } \\
\text { Del. }\end{array}$ & Anacardiaceae & Selbena & Salbana & Sh \\
\hline 22 & $\begin{array}{l}\text { Psychotria } \\
\text { orophila Petit }\end{array}$ & Rubiaceae & Shawbuno & Shawuno & Sh \\
\hline 23 & $\begin{array}{l}\text { Pterolobium } \\
\text { stellatum } \\
\text { (Forssk.) Brenan }\end{array}$ & Fabaceae & Beneka & Gorsa & C \\
\hline 24 & $\begin{array}{l}\text { Rhus natalensis } \\
\text { Krauss }\end{array}$ & Anacardiaceae & Kufure & Kufuri & Sh \\
\hline 25 & $\begin{array}{l}\text { Schoenoplectus } \\
\text { subulatus (Vahl) } \\
\text { Lye }\end{array}$ & Cyperaceae & Kontsele & Kuntsele & $\mathrm{H}$ \\
\hline 26 & $\begin{array}{l}\text { Solanum } \\
\text { americanum } \\
\text { Mill. }\end{array}$ & Solanaceae & Tsepe & Tsepi & $H$ \\
\hline 27 & $\begin{array}{l}\text { Teclea nobilis } \\
\text { Del. }\end{array}$ & Rutaceae & Tsaki & & Sh \\
\hline 28 & $\begin{array}{l}\text { Terminalia } \\
\text { brownii Fresen. }\end{array}$ & Combretaceae & Ara & Ara & $\mathrm{T}$ \\
\hline 29 & $\begin{array}{l}\text { Zanthoxylum } \\
\text { chalybeum } \\
\text { Engl. }\end{array}$ & Rutaceae & Gedek & Gedeka & Sh \\
\hline
\end{tabular}

\section{Acknowledgements}

We would like to acknowledge the Benna-Tsemay and Hamer District administrators for their cooperation and assigning field assistants. Besides, we would like to thank all the informants, group discussion participants, agriculture extension workers (field assistants), and local language translator for their generous, committed participation and sharing of their knowledge and experience on the uses of $P$. thonningii. We are grateful to Alison Power (Prof.), Morgan Ruelle (Dr.), Alex McAlvay (Dr.), and Sarah Tewolde-Berhan (Dr.) for their training support under the McKnight Foundation Collaborative Crop Research Program. The main author is grateful to IDEA WILD for providing office and field material support. We acknowledge Ethiopia's Minstry of Education and the McKnight Foundation Collaborative Crop Research Program for their training and financial support for field data collection.

\section{Authors' contributions}

MB designed the study, carried out the data collection, analyzed the data, and wrote the manuscript. ZW, ZA, and EL assisted the study area and 
species selection, revised the manuscript critically, and made considerable input for its enrichment to the present form. All authors read and approve the manuscript to reach its final form and agreed on its submission.

\section{Funding}

This work was supported by Ethiopia's Ministry of Education, and the McKnight Foundation Collaborative Crop Research Program. They provide us financial support for field data collection

\section{Availability of data and materials}

All the data used to support this study have been deposited in the Dryad repository (Available at: https://doi.org/10.5061/dryad.9p8cz8wg3)

\section{Declarations}

\section{Ethics approval and consent to participate}

The study was approved after an official permission letter from Addis Ababa University, Department of Plant Biology and Biodiversity Management and submitted to the Benna-Tsemay and Hamer District Administrative and Kebele Administrative Offices. Verbal consent was also obtained from each and all informants who participated in the individual and group discussions after explaining the main objectives of the study with assistance of local language translators.

\section{Consent for publication}

"Not applicable" in this section

\section{Competing interests}

The authors declare that they have no competing interests.

\section{Received: 14 April 2021 Accepted: 22 June 2021}

Published online: 17 July 2021

\section{References}

1. Orwa, C., Mutua, A., Kindt, R., Jamnadass, R., \& Simons, A. (2009). Agroforestree database: A tree reference and selection guide. Version 4. Agroforestree Database: a tree reference and selection guide. Version 4.

2. Thulin, M., Hedberg, I., \& Edwards, S. (1989). Fabaceae Subfam. Papilionoideae. Flora of Ethiopia, 3, 97-251.

3. Bekele, A., \& Tengnäs, B. (2007). Useful trees and shrubs of Ethiopia: identification, propagation, and management for 17 agroclimatic zones: RELMA in ICRAF Project, World Agroforestry Centre, Eastern Africa Region

4. Assefa A, Abebe T. Wild edible trees and shrubs in the semi-arid lowlands of Southern Ethiopia. J Sci Dev. 2011;1(1):5-19.

5. Tebkew M, Gebremariam Y, Mucheye T, Alemu A, Abich A, Fikir D. Uses of wild edible plants in Quara District, Northwest Ethiopia: implication for forest management. Agric Food Secur. 2018;7(1):1-14.

6. Amente DA. Ethnobotanical survey of wild edible plants and their contribution for food security used by Gumuz people in Kamash Woreda; Benishangul Gumuz Regional State; Ethiopia. J Food Nutrition Sci. 2017;5(6): 217.

7. Dasofunjo K, Nwodo O, Yakubu O, Ejoba R, Ukpanukpong R, Ipav S, et al. Toxicological implication of ethanol leaf extract of Piliostigma thonningii on renal function indices of male Wistar Albino rats. Eur J Exp Biol. 2013;3(3): 652-5.

8. Tadesse W, Desalegn G, Yirgu A. Forestry and forest products: technologies and issues. Ethiopia: Retrieved from Addis Ababa; 2012.

9. Ayenew A. Utilization and nutritive value of Piliostigma thonningii as ruminant feed in North Western Ethiopia. Ethiop J Appl Sci Technol. 2019; 10(2):1-10.

10. Chidumayo EN. Long term impacts of crop cultivation and tree shading on Piliostigma thonningii (Schumach) Milne-Redhead population, growth and biomass production after charcoal production in Central Zambia. Glob Ecol Conserv. 2018;13:e00373.

11. Egharevba HO, Kunle FO. Preliminary phytochemical and proximate analysis of the leaves of Piliostigma thonningii (Schumach.) Milne-Redhead. Ethnobotanical Leaflets. 2010, 2010;(5):2

12. Jemiseye F, Akinlade J, Ogunwole O, Adedeji B. Piliostigma thonningii leaves as dry season feed supplement for West African dwarf goats. Niger J Anim Prod. 2019;46(2):276-83.
13. Jimoh F, Oladiji A. Preliminary studies on Piliostigma thonningii seeds: proximate analysis, mineral composition and phytochemical screening. Afr J Biotechnol. 2005;4(12).

14. Baldé $A$, Traoré $M$, Baldé $M$, Barry M, Diallo A, Camara $M$, et al. Ethnomedical and ethnobotanical investigations on the response capacities of Guinean traditional health practioners in the management of outbreaks of infectious diseases: the case of the Ebola virus epidemic. J Ethnopharmacol. 2016;182: 137-49.

15. Deshi SN, Wonang DL, Dongs IS. Exploration of Piliostigma thonningii (Schum.) a tropical tree for possible utilization as a plant-derived pesticide. Acad J Interdiscip Stud. 2014;3(7):108.

16. Dluya T, Dahiru D. Antibacterial activity of Piliostigma thonningii methanol stem bark extract. Int J Res Pharm Biosci. 2018;5(1):15-20.

17. Musah M. Phytochemical screening, mineral determination and antimicrobial screening of the leaves extracts of Piliostigma thonnongii (Matured and Young) leaves. Afr J Agric Food Sci. 2019;2(1):15-27.

18. Ukwuani A, Ihebunna O, Samuel R, Peni I. Acute oral toxicity and antiulcer activity of Piliostigma thonningii leaf fraction in Albino rats. Bull Env Pharmacol Life Sci. 2012;2:41-5.

19. Ruffo, C. K., Birnie, A., \& Tengnäs, B. (2002). Edible wild plants of Tanzania. : Regional land management unit (RELMA): Swedish International Development Cooperation Agency (Sida), Nairobi, Kenya

20. EIAR. Ethiopian Institute of Agricultural Research: Coordination of National Agricultural Research System, Ethiopia. Ethiopia: Retrieved from Addis Ababa; 2011.

21. Friis, I., Demissew, S., \& Breugel, P. v. (2010). Atlas of the potential vegetation of Ethiopia. The Royal Danish Academy of Science and Letters, Biologiske Skrifter 58: Det Kongelige Danske Videnskabernes Selskab.

22. CSA. The 2007 Population and Housing Census of Ethiopia Result by Region, Sex and Place of Residence. Ethiopia: Retrieved from Addis Ababa; 2007.

23. Addis G, Asfaw Z, Woldu Z. The role of wild and semi-wild edible plants to household food sovereignty in Hamar and Konso Communities, South Ethiopia. Ethnobotany Res Appl. 2013;11:251-71.

24. Terefe A, Ebro A, Tessema Z. Rangeland dynamics in South Omo Zone of Southern Ethiopia: assessment of rangeland condition in relation to altitude and grazing types. Livestock Res Rural Dev. 2010;22(10).

25. Adem M, Worku A, Lemenih M, Tadesse W, Pretzsch J. Diversity, Regeneration Status and Population Structure of Gum-and Resin-Bearing Woody Species in South Omo Zone, Southern Ethiopia. J Forestry Res. 2014; 25(2):319-28.

26. Guinand $Y$, Lemessa D. Wild-food plants in Ethiopia: reflections on the role of wild foods and famine foods at a time of drought. Potential Indigenous Wild Foods. 2001;22:31.

27. Kidane L, Kejela A. Food security and environment conservation through sustainable use of wild and semi-wild edible plants: a case study in Berek Natural Forest, Oromia Special Zone, Ethiopia. Agric Food Secur. 2021;10(1):1-16.

28. Molla EL, Asfaw Z, Kelbessa E, Van Damme P. Wild edible plants in Ethiopia: a review on their potential to combat food insecurity. Afrika Focus. 2011; 24(2):71-121.

29. Kotrlik, J., \& Higgins, C. (2001). Organizational research: determining appropriate sample size in survey research appropriate sample size in survey research. Information technology, learning, and performance journal, 19(1), 43.

30. Ministry-of-Agriculture. (2014). Productive safety net programme phase IV: Programme Implementation Manual. Addis Ababa, Ethiopia. Version 1.0.

31. Martin G. Ethnobotany: A Methods Manual. Nowy Jork: Chapman Y Hall; 1995.

32. Alexiades MN. Collecting ethnobotanical data: an introduction to basic concepts and techniques. Adv Econ Botany. 1996;10:53-94.

33. Cotton CM, Wilkie P. Ethnobotany: principles and applications. London: John Wiley \& Sons Chichester; 1996.

34. Zeigler $\mathrm{DH}$. Young adults as a cognizable group in jury selection. Michigan Law Rev. 1978;76(7):1045-110.

35. Mettler S, Bosshard JV, Häring D, Morgan G. High prevalence of supplement intake with a concomitant low information quality among Swiss fitness center users. Nutrients. 2020;12(9):2595.

36. Pashardes, P. (2011). Promoting social inclusion of immigrants in Cyprus: a study of national policies.

37. Kacholi, D. S. (2014). Edge-interior disparities in tree species and structural composition of the Kilengwe Forest in Morogoro Region, Tanzania. International Scholarly Research Notices, 2014. 
38. Amjad MS, Arshad M. Ethnobotanical inventory and medicinal uses of some important woody plant species of Kotli, Azad Kashmir, Pakistan. Asian Pac J Trop Biomed. 2014;4(12):952-8.

39. Demel, T., Feyera, S., Mark, M., Million, B., \& Pia, B. (2010). Edible wild plants in Ethiopia. Addis Ababa University Press, Ethiopia by Eclipse Private Limited Company. Retrieved from

40. Awas T, Asfaw Z, Nordal I, Demissew S. Ethnobotany of Berta and Gumuz people in Western Ethiopia. Biodiversity. 2010;11(3-4):45-53.

41. Bortolotto IM, de Mello Amorozo MC, Neto GG, Oldeland J, Damasceno-Junior GA. Knowledge and use of wild edible plants in rural communities along Paraguay River, Pantanal, Brazil. J Ethnobiol and Ethnomed. 2015;11(1):1-15.

42. Teklehaymanot T. An ethnobotanical survey of medicinal and edible plants of Yalo Woreda in Afar regional state, Ethiopia. J Ethnobiol Ethnomed. 2017; 13(1):1-26.

43. Alemayehu G, Asfaw Z, Kelbessa E. Plant diversity and ethnobotany in Berehet District, North Shewa Zone of Amhara Region (Ethiopia) with emphasis on wild edible plants. J Med Plants Stud. 2015:3(6):93-105.

44. Dalle G, Maass B, Isselstein J. Plant biodiversity and ethnobotany of Borana pastoralists in Southern Oromia, Ethiopia. Econ Botany. 2005;59(1):43-65.

45. Teklehaymanot T, Giday M. Quantitative ethnobotany of medicinal plants used by Kara and Kwego semi-pastoralist people in Lower Omo River Valley, Debub Omo Zone, Southern Nations, Nationalities and Peoples Regional State, Ethiopia. J Ethnopharmacol. 2010;130(1):76-84.

46. Pawera L, Khomsan A, Zuhud EA, Hunter D, Ickowitz A, Polesny Z. Wild food plants and trends in their use: from knowledge and perceptions to drivers of change in West Sumatra, Indonesia. Foods. 2020;9(9):1240.

47. Hidosa D, Ayele B, Mengistu M. Participatory on-farm evaluation and demonstration of improved legume forage species in Benatsemay Woreda of South Omo Zone. J Biol Agric Healthc. 2015;5(21).

48. Asfaw Z, Tadesse M. Prospects for sustainable use and development of wild food plants in Ethiopia. Economic Botany. 2001;55(1):47-62

49. Balemie K, Kebebew F. Ethnobotanical study of wild edible plants in Derashe and Kucha Districts, South Ethiopia. J Ethnobiol Ethnomed. 2006; 2(1):1-9.

50. Reta, H. T., Demissew, S., Asfaw, Z., \& Zewdu, A. (2019). Micronutrient and phytic acid contents of wild edible fruits collected from Temcha watershed of Amhara Region (Ethiopia) to combat hidden hunger.

51. Poulton C, Poole N. Poverty and fruit tree research, Dfid Issues and Options Paper. Kent, England: Forestry Research Programme. Imperial College at Wye; 2001.

52. Awas, T. (2007). Plant Diversity in Western Ethiopia: Ecology, Ethnobotany and Conservation.

53. Adhikari J, Ojha H, Bhattarai B. Edible forest? Rethinking Nepal's forest governance in the era of food insecurity. Int Forestry Rev. 2016;18(3):265-79.

54. Jeambey Z, Johns T, Talhouk S, Batal M. Perceived health and medicinal properties of six species of wild edible plants in North-East Lebanon. Public Health Nutr. 2009:12(10):1902-11.

55. Belayneh A, Asfaw Z, Demissew S, Bussa NF. Medicinal plants potential and use by pastoral and agro-pastoral communities in Erer Valley of Babile Wereda, Eastern Ethiopia. J Ethnobiol Ethnomed. 2012;8(1):1-11.

56. Dejene T, Agamy MS, Agúndez D, Martin-Pinto P. Ethnobotanical survey of wild edible fruit tree species in lowland areas of Ethiopia. Forests. 2020; 11(2):177.

57. Nwosu OE, Inuwa HM, Onyike E, Dingwoke J. Detection and isolation of novel lectin gene from Piliostigma thonningii seeds. Am J Biochem. 2016;6:72-81.

58. Maćkowiak, K., Torlińska-Walkowiak, N., \& Torlińska, B. (2016). Dietary fibre as an important constituent of the diet. Advances in Hygiene \& Experimental Medicine/Postepy Higieny i Medycyny Doswiadczalnej, 70.

59. Geta T, Nigatu L, Animut G. Ecological and socio-economic importance of indigenous multipurpose fodder trees in three districts of Wolayta Zone, Southern Ethiopia. J Biodivers Endangered Species. 2014;2(4):136-8.

60. Wood, P. J., \& Burley, J. (1991). A tree for all reasons: introduction and evaluation of multipurpose trees for agroforestry. London, UK.

61. Woldu Z, Fetene M, Abate A. Vegetation under different tree species in acacia woodland in the Rift Valley of Ethiopia. Sinet Ethiop J Sci. 1999;22(2): 235-52

62. Gebreegziabher, Z. (2007). Household Fuel Consumption and Resource Use in Rural-Urban Ethiopia.

63. Eastaugh C, Cheteu LB, Cobbinah J, Dwomoh F, Foahom B, Foli E, et al. Climate change impacts on African forests and people. IUFRO Occas paper. 2010;24.
64. Feyisa BN, Feyssa DH, Jiru DB. Fuel wood utilization impacts on forest resources of Gechi District, South Western Ethiopia. J Ecol Nat Environ. 2017; 9(8):140-50.

65. Bekele M. Forestry Outlook Studies in Africa (Fosa). Ethiopia: Country Report; 2001

66. Mekonnen, A., \& Köhlin, G. (2009). Determinants of household fuel choice in major cities in Ethiopia.

67. Kidane B, van Andel T, van der Maesen LG, Asfaw Z. Use and management of traditional medicinal plants by Maale and Ari Ethnic communities in Southern Ethiopia. J Ethnobiol Ethnomed. 2014;10(1):1-15.

68. Awhin E, Jeroh E, Anigboro A, Rachael N. Effect of cronic consumption of Piliostigma thonningii on activities of alanine aminotransferase and aspartate aminotransferase in serum and liver in Rattus novergicus. Pak J Biol Sci. 2013;16(24):2062-5.

69. Usman R. Phytochemical screening, mineral determination and antimicrobial screening of the leaves extracts of Piliostigma thonnongii (matured and young) leaves. Afr J Agric Food Sci. 2019;2(1):15-27.

70. Reilly MJ, Wimberly MC, Newell CL. Wildfire effects on plant species richness at multiple spatial scales in forest communities of the Southern Appalachians. J Ecol. 2006;94(1):118-30.

71. Burkle LA, Myers JA, Belote RT. Wildfire disturbance and productivity as drivers of plant species diversity across spatial scales. Ecosphere. 2015;6(10): $1-14$.

72. FAO. (2017). Analysis of forests and climate change in Eastern Africa: forests and climate change working paper 16. . Retrieved from Rome::

73. Dandena G. Shifting to alternative food source: potential to overcome Ethiopias' malnutrition and poverty problems. Paper presented at the Proceedings of a symposium on Innovation and Sustainable Development in Agriculture and Food. France: Montpellier; 2010.

74. Cao Y, Li R, Zhou S, Song L, Quan R, Hu H. Ethnobotanical study on wild edible plants used by three trans-boundary ethnic groups in Jiangcheng County, Pu'er, Southwest China. J Ethnobiol Ethnomed. 2020;16(1):1-23.

75. Kebebew M, Leta G. Wild edible plant bio-diversity and utilization system in Nech Sar National Park, Ethiopia. Int J Bio-resource Stress Manage. 2016;7(4): 885-96.

76. Gandile AU, Tessema SM, Nake FM. Biodiversity conservation using the indigenous knowledge system: the priority agenda in the case of Zeyse, Zergula and Ganta communities in Gamo Gofa Zone (Southern Ethiopia). Int J Biodivers Conserv. 2017;9(6):167-82.

77. Carvalho AM, Frazão-Moreira A. Importance of local knowledge in plant resources management and conservation in two protected areas from TrásOs-Montes, Portugal. J Ethnobiol Ethnomed. 2011;7(1):1-13.

\section{Publisher's Note}

Springer Nature remains neutral with regard to jurisdictional claims in published maps and institutional affiliations.

\section{Ready to submit your research? Choose BMC and benefit from:}

- fast, convenient online submission

- thorough peer review by experienced researchers in your field

- rapid publication on acceptance

- support for research data, including large and complex data types

- gold Open Access which fosters wider collaboration and increased citations

- maximum visibility for your research: over $100 \mathrm{M}$ website views per year

At BMC, research is always in progress.

Learn more biomedcentral.com/submissions 